\title{
La Onda: The Gatekeepers and the Replicants
}

\section{Isaac Bickmore}

North Kansas City School District, Missouri (USA)

Joni Yessenia Sanchez is a (fictional) freshman music education major with the special ability to control sound waves with her mind. We meet her in her second semester as she happens upon the plot of a couple of extra-terrestrial visitors who plan to take over the world, while Joni is also deciding not to major in music education anymore. We witness her negotiation as she transitions out of music education and transforms into La Onda, a superhero for our times. She might be the hero that our profession needs. Will she actually leave the degree? Will she step up and save her classmates and the world? Is our profession ready to welcome a superhero like Joni?

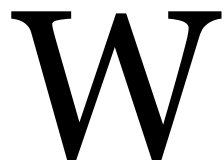

ho are music education degree programs designed to attract, recruit, and retain? What narratives about music teaching and learning, about who belongs and who does not, do we convey to future, present, and past students through the musical practices, repertoire, curriculum, pedagogy, and research of the profession? Why are there so few students of color in music education programs? The story you are about to read serves to trouble certainty in the field of music education (Barrett and Stauffer 2009), particularly the certainty that music education degrees work for everyone who wants to be a music teacher.

In Fiction as Research Practice, Patricia Leavy (2016a), who prefers that research framed as fictional writing "stand more or less on its own as an artistic work," suggests that the writer has numerous ways of signaling that a work is fictional, as well as various ways of disclosing, if the author chooses, both the purposes of the work and how the work was created (74). To that end, this superhero origin story responds to the call for papers for the special issue of Action, Criticism, and Theory in Music Education on narrative inquiry. Specifically, I address two questions from the call: How or in what ways might narrative inquiry make evident the means and meanings of musical lives of individuals and musical

(C) Isaac Bickmore. The content of this article is the sole responsibility of the author. The ACT Journal and the Mayday Group are not liable for any legal actions that may arise involving the article's content, including, but not limited to, copyright infringement. 
communities of practice? How or in what ways does (or could) narrative inquiry engage or connect not only discourses in/of music and education, but also broader social, cultural, and political discourses?

Joni Yessenia Sanchez, the protagonist in this story, is a (fictional) freshman music education major with the special ability to control sound waves with her mind. Joni is a composite character, similar to composite characters found in artsbased scholarship and the fiction-based research of Leavy and others (e.g., Blanchard and Casanova 1996; Leavy 2015, 2016b; see also the journal Art/Research International). Joni is based on conversations, interviews, projects, and research with people of varying ethnicities and backgrounds who have left music education degrees, and people who are struggling to stay in these degrees or may be questioning why they should stay. Joni navigates through social, cultural, and political discourses as a young Latinx woman in the predominantly White context of a college music education program.

Myra Infante Sheridan, whose commentary and general editing advice was supremely helpful in shaping this story, commented in response to one iteration of this manuscript, "Ideologically, I prefer that brown people tell their own stories. Why does she have to be Latinx?" I had already been thinking about my positionality as a White male (among other privileged positions) and the nature of this story. My answer to Myra was, "I started this as a study of why people are leaving music education degrees. I noticed the lack of diversity in music education degree programs. I also noticed that several people I knew who had left music education programs that $I$ was a part of were people of color. Joni is a composite character based on several people. Not all of them are Latinx but some are. It was important to me that this character be Latinx so that her decision to leave the degree represents what other researchers and I have noticed: music education has a whiteness problem. It was important to me that the story reflects how whiteness and the construction of whiteness in music education degree programs and the exclusion of Black and Brown voices and bodies is problematic. It was important to me that Joni embody and reflect that problem."

Narrative inquiry could, should, and does seek to engage with people who are missing from music and music education. Other scholars working in narrative and also in arts-based and other related forms of scholarship have examined race, racial diversity and the lack thereof in music and music education degree 
programs, as well as gender and gender identity, ableism, classism, and other forms of exclusion wielded against those who seek to teach, those who are already teachers, and those who simply wish to participate in music making (e.g., Bartolome 2016; Bradley 2007; DeLorenzo and Silverman 2016; Hendricks and Dorothy 2017; Hess, 2019; Koza 2008; Lechuga and Schmidt 2017; McCall 2017; Minette 2018; Nichols 2013; Robinson and Hendricks 2017; Powell and Celeste 2020; Smith and Hendricks 2020; Talbot 2017). Joni embodies multiple intersectional positions. That intersectionality-the experience of it, the living of it-is not fictional. On the contrary, it is very much in keeping with the ways in which the people on whom Joni is based experience their lives, their music, and, for the purposes of this story, their transitions into and out of music education degree programs.

And what of Joni's superpowers, which are fictional. Or are they? Which ones? To whom?

I hope that this story might engage multiple audiences in discussions about access to post-secondary music education and music teaching as a profession in the same ways that other works of fiction are used to explore violence, schooling, racism, gender identity, and other critical social problems (see, for example, Robin Patric Clair's Zombie Seed and the Butterfly Blues 2013). In this story, Joni navigates the institutionalized racism of the school of music she attends by navigating away from it. Like Joni, students (and not just undergraduate students) make decisions informed by very real barriers that are sustained by institutional inability to change. If the very White faculties of tertiary schools of music cannot, once and for all, reject a Eurocentric, White-centric, racist curriculum and work towards a student-centered, anti-racist, culturally relevant and sustaining curriculum, why should Joni stay? If we can't say that Black and Brown lives matter out loud and show it through active inclusion and forthright invitation of Black and Brown voices and bodies into the histories and repertoire and the programs and practices of music learning and teaching, why would she want to stay? This is why I wrote the story. 


\section{La Onda: The Gatekeepers and the Replicants}

Dr. Daynes was sitting in his office late one evening. He had been thinking about how to encourage his students to take more ownership of their education. He was planning a project for his Introduction to Music Education class that involved having them choose an area of interest and then plot out a series of readings for themselves, perhaps in small groups. His back was to the door when it burst open. He gasped. He thought he had locked it. He turned away from his standing desk and saw a man wearing a plumber's uniform entering his office, followed directly by a woman in a black suit and tie. As they entered, Dr. Daynes began to ask, "Can I help you?"

And as he did, the woman asked the man in the plumber's uniform, "Is this him? Is this a gatekeeper?"

"Yes, he decides. My research is conclusive," the man replied.

"You'd better be right," the woman said.

"Excuse me?" Dr. Daynes asked, his voice trembling noticeably. "I am a professor of music education. I don't know what you are talking about ... gatekeepers and ... who are you? I think you are mistaken."

The woman approached Dr. Daynes quickly and pushed him into his desk.

"No wait," he protested as he fell back. He turned and grabbed his computer keyboard and aimed a swing at the woman, who easily dodged the intended blow. She pushed his arm away from him, spinning him around so his back was facing her. She shoved his arm up into his back and secured him to the desk. She put her mouth close to his ear and began to sing.

"What are you doing?" Dr. Daynes said as he struggled to free himself from her grasp. The words of her song were in no language he could decipher. In fact, the song sounded inhuman. She was singing multiple pitches at the same time, and the music resonated throughout his whole body. It didn't hurt him, but it shook him. He felt his consciousness slipping and tried to free himself.

"Please stop," he said. "Why are you doi...." His body went limp, and he was out.

Bickmore, Isaac. 2022. La Onda: The gatekeepers and the replicants. Action, Criticism, and Theory for Music Education 21 (1): 171-98. doi:10.22176/act21.1.171 
The woman picked him up and draped him over her shoulder as if he were a child. She walked over to the man in the plumber's suit, who had stayed by the door the whole time.

"Are you ready to take his place?"

The man closed his eyes and took a deep breath. He put his hand on Dr. Daynes' head, breathed deeply again, and began to sing. The singing was not loud, but it was resonant. His song was short, and as he sang, his whole body transformed into an exact replica of Dr. Daynes. The woman set Dr. Daynes down, started taking off his clothes, and threw them at the replicant who was taking off the plumber's uniform. Suddenly she stopped. "Someone is coming. I thought you checked the building!"

The replicant of Dr. Daynes looked back and forth as if he was listening for something. "I did. I sensed no vibrations on any floor. People aren't usually here at this hour."

"Seal the room," the woman ordered. She picked up Dr. Daynes and the plumber's uniform, stepped into the closet in the office and closed the door. The replicant quickly finished buttoning up Dr. Daynes's shirt, put his hands in the air, and closed his eyes. When he opened his eyes, there was no sound coming in from outside the office and no sound leaving the office. He had sonically sealed the room. He looked into the mirror by the door and saw Dr. Daynes looking back at him. His transformation had worked. He stood at the desk and waited for whomever was about to knock.

\section{Meet Joni}

The following 4 things are absolutely $100 \%$ true:

1. My name is Joni Yessenia Sanchez,

2. I play bass guitar in my mom's praise band,

3. I can control sound waves with my mind, and

4. I am not going to major in music education anymore.

\section{Fact \#1: The Name}

Joni is from my mom and Yessenia is from my dad. My mom loves Joni Mitchell (it's an obsession), so that's how I got Joni-ed. Mom also did missionary work in 
Nicaragua in the late 9os, and let's just say she didn't only bring people to Jesus, she also brought my dad back to the States. Now my parents live in Blue Springs, Missouri. Yessenia is my grandma's name on my dad's side. He says that I am a lot like her. My grandma and grandpa own a melon farm in Nicaragua. My dad says my grandma is smart and independent, just like me. I don't know about the smart part, but I try to do things my own way. I have only met grandma twice, but my dad has pictures of her, and we definitely look alike.

Fact \#2: The Bass

My mom is a music worship leader at our church. She sings and plays keys. My dad plays drums and sings some, too. I play the bass. I started playing when I was 14. I have always been good at music. I sing in the praise band, too, but the bass is my true love. I love how it feels. I love to stand in front of my amp and let the sound surround me.

My bass heroes:

1. Esperanza Spalding

2. Carol Kaye

3. Janelle Monáe (I know she is not a bass player, but she is still one of my bass heroes 'cause Afrofuturism and dirty computers, so back off.)

\section{Fact \#3: The Powers}

The way I interact with sound is different than other people. My mom says that when I was really young, like as a baby, I could make sounds that I didn't like disappear. She says my dad would be watching a soccer game and if it got really loud, like someone would score or something, I would look at the TV and the sound would go away. For a while they thought there was something wrong with the electronics in the house. As soon as they realized it only happened when I was in the room, they started testing the theory. They plopped me in the middle of the living room in front of the stereo and turned-on different music and tv shows. If I liked it, I "turned it up," and if I didn't, I "turned it down." The best way to describe it is, I am like a pair of noise cancelling headphones. I can do more than cancel the sound, though. I can control the sound waves around me. It got weird when my mom's sister came over. I guess I didn't like her voice. She thought she was losing 
her hearing, but really, I was canceling out her voice. I can also protect my own ears when I make things really loud.

My parents helped me figure things out before I started school. My dad is a mechanical engineer, and my mom is a first-grade teacher. My dad started to figure out what I was doing, and my mom translated it into words I could understand. I can take a sound wave and double it or replicate it out of sync. I can concentrate sound waves in a certain area. I can use the concentration of sound waves kind of like echolocation because my mind can kind of visualize where the sound is traveling. I can do this with any sound source.

When I was three, we drove to Kansas City. While we were walking around seeing the sights, an ambulance came down the street. As it approached, the siren disappeared, and I was crying. As it passed us, the siren came back on, like a reverse Doppler effect. People looked around to figure out why the siren stopped working. My parents knew, and they tried to get me back to the car as fast as they could. I used to not realize I was doing it. Once at a movie, Madagascar, I loved the song they were singing so much that I turned it up. I was just bopping around to "I like to move it move it," and I looked, and my dad was covering his ears. Everybody was covering their ears. Only my dad knew it was me, but I was still embarrassed.

My parents worked with me to help develop the powers. I have learned to shut out the sounds I don't want to hear and to amplify those I do. I am really good at hearing things far away. All I have to do is just catch a little bit of it, and then I can mentally hone it. I can control it so well now that if a person is talking in another room or across the street, I can amplify part of the sound wave they are creating and streamline a wave just for me, and they can't even tell that I'm doing it. Now it sounds like I am just showing off. Moving on!

\section{Fact \#4: Not Majoring in Music Education Any More}

I started here at "The" Midwest University in Charlesville, Missouri, last semester as a music education major. I love music, and I want to teach little kids. In addition, the college was close and the best viable financial option. I was excited to come here at first. When I asked if I could audition with my bass and they told me it would have to be an acoustic orchestra-style bass; it is fair to say that there were some red flags. Instead of the bass, I decided to audition with my voice. When I

Bickmore, Isaac. 2022. La Onda: The gatekeepers and the replicants. Action, Criticism, and Theory for Music Education 21 (1): 171-98. doi:10.22176/act21.1.171 
called to ask some questions, a nice lady in the music office directed me to a website where I could find the kinds of songs I would need to sing for the audition. I searched for vocal solos and found a list of songs that I had never heard of. I needed to sing one in a foreign language and one in English, so I did some research and decided to sing "Caro Mio Ben" and "Oh Shenandoah." I found PDFs of both songs online, and they said that there would be someone to play the piano there. My mom helped me practice.

"Mom, why don't they let me try out with my bass?"

"I don't know, Jo," she said as she worked out the rhythm of the Italian piece. "Maybe it's because they don't have a bass teacher there."

"They have a guitar teacher. I Googled him and he plays the bass. He's better than me. For sure I could learn from him."

"Well maybe you could ask him when you get there. Are you worried about the audition?"

“I don't know. I just don't wanna learn to sing like the voice teachers there. They are great and everything, like, the videos I could find are amazing, but I just don't know if I want to sing like that."

"Well, Jo," Mom said, still playing through the Italian piece, "are you sure you want to major in music ed?"

"Yes. I want to teach little kids music for sure. Like Mr. Birch from elementary school. Like xylophones, boomwhackers, ukuleles, musical puppet shows, and projects and stuff."

"Ok, well, this is the way to get there, Jo." Turning towards me now, "It's not like you won't be able to play the bass again. It's not gonna hurt you to learn how to use your voice like that. You'll be excellent at it. You especially. You should be able to pick it up really quick with your ... uh ... powers or whatever."

I remember thinking she was right, but there was some part of the issue that was missing. I would be able to figure out the voice thing, but inside my gut there was a nagging feeling that hadn't fully formed at the time and has recently become clear. At the time, the feeling was, "Are they going to turn me into something I don't want to be?" Now the feeling has evolved into something more solid. "I am not going to major in music education anymore."

At the audition, the voice teachers were impressed with my voice. I am a very good mimic because of my "powers or whatever." I found a few good versions of 
the audition songs on Spotify. I was actually really excited to start after the audition. It's amazing what a little positive feedback and praise will do. They even gave me a little (very little) voice scholarship. Let's just say several things changed after that. I remember my first voice lesson with Dr. Gottfried. She has this amazing voice and has worked so hard, not just on her voice, but on her career. I really admire her for that. She is always singing in New York and other cities around the U.S. doing operas and stuff. So, in my first lesson, I was doing my mimic thing with my audition piece, and she was like, "That sounded really good, but it looked terrible. You looked like you were in pain. Does it hurt you to sing like that?”

I must have looked shocked or something because her expression changed from seriousness to full on laughter. "Joni, you have a great instrument," she said.

I looked around thinking I had accidentally brought my bass with me until I realized she was talking about my voice. I had never thought of my voice as an instrument before. I always thought about my voice as an extension of my ears and my powers. I could detect sound with my ears, create it with my voice, and manipulate it with my mind. This was a big idea for me. I basically tuned her out for the next few sentences while I had a big think about it. I just kept nodding as she talked and I thought to myself, "Sure, I mean, why not? My voice as an instrument." It was more like a piece of my whole body as an instrument. I could feel sound, caress it, push it, erase it, sing it, focus it, throw it, double and triple it, flip it, reverse it, make it do my dirty, and traverse it. (I like to make up rap lyrics in my head and share them with my friend Dee.) I do that all with my body. Singing is part of it, but only part of it. Music particularly is a whole-body experience for me, so I was down with this "my voice is an instrument" thing to a certain extent.

I don't know how that lesson ended, but I remember everything about the lesson when I told her I was thinking about changing majors.

"How are you doing Joni?" Dr. Gottfried asked.

"Doing good. How are you?” I replied.

"Great. How did your practicing go this week?"

"Really well," I lied. I hadn't even touched my music.

We ran through a series of warmups and after about five minutes my accompanist came in. Her name is Sophie, and she's a piano major. I have to pay her to be my accompanist, a fact that I was starting to feel in the wallet area. After the pleasant greetings were done, Dr. Gottfried asked if she could hear the German 
piece I was working on, "Lied der Mignon" by Schubert. It was getting close to the end of the semester, and I had to prepare for my jury. I was dreading it. It's not that I am afraid of performing. It's not that at all. I like performing sometimes. Particularly, I like performing when I get to play my bass and harmonize with my mom and dad. I don't even really like the church music that we sing necessarily, but the musical experience I have with my parents is special. It is collaborative, and we improvise things. We play off each other. I can't really explain it.

I really hate singing the way Dr. Gottfried asks me to sing. I hate the sound of my voice when I sing like that. I understand why people used to sing that way. People used to have to sing without microphones and stuff and they had to sing over the orchestras. I just have never liked opera. I don't know anybody that likes to listen to it. Like, if you look at your friends' or even your parents' Spotify playlists, you are not going to find any opera on there. It's not that the music isn't beautiful or well crafted, it's just not my scene ... or anybody's scene anymore really. I know that every big city has an opera company, and I know that people still listen to it. But can't I learn to use my voice in other ways? Life is too short to spend four years or more singing music I don't really care about.

I can hear Dr. Gottfried in my mind right now saying, "It isn't all opera, Joni." So, I get it. I know opera is just a word I am using as a catchall for music that I don't like. It is an aesthetic (I took A.P. Humanities, ok). It is an aesthetic that I don't like. I like Janelle Monáe, I like Aretha Franklin, I like Lauryn Hill, I like my parents' music. I like Childish Gambino, Al Green, Ella Fitzgerald, the Beach Boys, Motown, Frank Sinatra. Crap, to completely contradict myself, I like to listen to some opera sometimes. I think there is a piece by Offenbach in one of my playlists that I only skip sometimes. The point is ...

"I don't think I can sing that song, Dr. Gottfried."

"What do you mean? I know that you can sing it. I have heard you sing it. You definitely have the potential to sing the pants off that song!"

"I know but ... I can't sing it, ya know? I don't feel anything for this song."

"Do you know what it means?"

"Yeah, she is, like, longing for this guy and he's far away and you can only know what she suffers if you know longing." She looked at me like I had lobsters coming out of my ears.

“Also, her vitals are aflame," I suddenly remembered out loud. 
"Joni. Wow. You really did your homework," she eventually said after being surprised for a couple of seconds. I didn't practice singing it, but I did look up the translation.

"It actually reminds me a little bit of a Lana Del Rey song 'Video Games.' Have you heard it?"

"No, I don't think I have," Dr. Gottfried replied.

"Same deal as this song. She loves this boy who doesn't really love her. She would do anything for him, and he kind of just wants to play video games. I mean, I am kind of simplifying it, but that is the gist," I explained.

"Ok. So what are you saying?" Dr. Gottfried asked. "It's kind of late in the game to change songs. You have to prepare a foreign language song for your jury, and we are cutting it very close. Also, you already know this song. It's nearly ready."

"I know," I said looking at my stupid shoes. Why do I do that? I shouldn't have acted like I was ashamed of what I was about to say. "I think I am going to drop out of the music ed degree."

"What? Why Joni?" She looked like she had just seen me yell at a puppy.

"Why?" I asked her question back at her and then shrugged my shoulders. "There are a lot of reasons. It's not you. It's a combination of things really."

"I would really like to know, if you wouldn't mind telling me," she said kindly.

"So ..." I began tentatively, constructing my reasons as I began to speak. I had never really said this out loud to anyone, but I trusted Dr. Gottfried. "I came here because I wanted to be a general music teacher. I want to teach little kids' music like my elementary music teacher Mr. Birch. Like xylophones, boomwhackers, ukuleles, musical puppet shows, musical projects, and stuff." (I don't care what Devon Campbell from my fourth-grade class said, I loved those damn goofy sock puppet musicals.) "I never heard Mr. Birch say anything about singing like this. I wasn't ever in choir in high school 'cause I didn't want to be. Here I have to be in choir and take voice lessons."

"What about band? I hear you are pretty good at a lot of instruments. I was talking to Dr. Winthrop about his instrument lab course. He says you are good," she interjected.

"Well, my instrument is the electric bass, and they don't offer electric bass lessons. I don't want to do upright bass. Voice was my best option if I couldn't do bass. I also don't fit in here. I was never in band or choir, and I don't get the whole 
marching band thing or whatever. I am fine with the theory and musicianship stuff. Did you know I only get to take two courses with Dr. Daynes about general music? If I want to be a general music teacher, why is so much of my time spent on choir and voice stuff?"

"But Joni, exploring new ensembles or styles of music is what every student needs to do. Everyone who goes on to teach explores and discovers new sorts of music. Don't limit yourself to what you already know. Growth only happens outside your comfort zone."

She paused for a moment. I could tell she was thinking and choosing her words carefully. "These are all great questions, Joni. I don't know the answers to them. It seems like you have been thinking a lot about this."

I had been thinking about this since day one. Since the very first time I saw the books I had to buy for lessons. Since the first choir rehearsal. Since the first time I looked around at my peers and realized I was the only one who looked even remotely like me. Except for maybe Brian, but he was graduating next semester. Not that it was the most important thing to me to look like everybody, it's just that high school was bad enough with only a few of us that were Latinx, but here it was even worse. It's nice to have someone who can understand that not everyone who speaks Spanish is from Mexico. It's not like all white people are like that, but so many people just automatically assume that I am from Mexico. Hello people! I am from Missouri! My dad is from Nicaragua. I was born right here in Blue Springs.

"Yes. I have been thinking a lot about this," I replied.

"Well, I hope you think just a little more about it before you decide to actually leave the degree. We would certainly miss you," Dr. G said kindly.

After that lesson a week ago, I thought more about it like Dr. Gottfried had asked me. I was thinking about it a couple of nights ago when I heard something weird in the music building. I was down in the basement in a practice room listening to music and doing homework. I like to stay in the music building really late, like, until after the custodians are done. I know them by name now. When they leave, I practice music, work on homework, and try things out with my powers. I can do this thing where I create a sound bubble. Basically, I can limit how far my sound travels. The bubble creates a buffer between my immediate surroundings and the rest of the world. Any sound I make in my space only stays where I am and sound from the outside world stays out. Like I said before, I am like a pair of noise

Bickmore, Isaac. 2022. La Onda: The gatekeepers and the replicants. Action, Criticism, and Theory for Music Education 21 (1): 171-98. doi:10.22176/act21.1.171 
canceling headphones. I can't keep it up forever though. It takes a certain amount of concentration and focus. Not all my concentration and focus, but still, a girl can only do so much.

So that night, when I let down the sound bubble buffer, I heard/felt the weirdest sound waves I had ever heard/felt. I immediately did what I call a scan. I close my eyes and visualize the building or the area around me and search for the source of vibrations. I am really good at this. My friend Dee and I test it out all the time. Dee is the only person other than my mom and dad who knows about my powers. She is amazing. She is majoring in computer programming. She is also good at making beats and stuff on her computer. We make recordings all the time and put stuff out on SoundCloud sometimes. Anyways, if we were in her house or mine, she would try to hide from me. The rules are, I have to plug my ears and not use my powers for two minutes to give her time to find a place. She hides and then I do a scan and send her a text telling her exactly where she was. I can hear her heartbeat. Even if she holds her breath and is completely silent, I can find her in like five seconds.

That night in the music building, the sound was faint but so distinct that it was easy to trace it back to its origin. The sound was reverberating throughout the whole structure, but I could tell right away that the weird sound (Was it singing or two people singing? Was it coming from a speaker or was it live?) was coming from the offices three floors above me. The weird sound only lasted about 15 seconds and then it was gone. I decided to go and check it out. I started gathering my things and kept listening. Even though the weird sound was gone, I could still hear activity. It wasn't clear what was going on. Then I heard voices.

“Are you ready to take his place?” It was a woman's voice.

Then I heard another sound that made the whole building buzz. I finished gathering my things as quickly as I could and left the practice room. As soon as I shut the door to the practice room, the sound upstairs stopped. That was odd. I listened carefully as I walked.

"Someone is coming. I thought you checked the building!" It was the woman's voice again.

"I did. I sensed no vibrations on any floor. People aren't usually here at this hour." A man's voice.

"Seal the room," the woman again. Seal the room? What a weird thing to say. 
I got up to the next level and the sounds stopped completely. I had been focusing on exactly where the sound had been coming from and now there was nothing. I was starting to get worried. Then the thought occurred to me, briefly, that I might be getting into some trouble. The thought didn't slow my roll though. I kept on walking up the stairs to the third level. I opened the door that led down the hall and realized right away that the sound had been coming from Dr. Daynes's office. He is my Intro to Music Ed professor. He is kinda goofy, but so am I, so I don't hold it against him. I started walking towards his office with my heart racing. I approached his door slowly and looked through the small window in the door to see what was going on. I saw him. He was putting on a zip-up hoodie, but I couldn't hear any sounds in the room. I knocked on the door and took a step back, feeling kinda relieved to see him but not completely. I wanted an explanation for the weird sounds and why they had disappeared.

He opened the door, and suddenly I could hear everything in the room. It was like he had made a sound bubble, like I did down in the practice room, but now it was gone. I quickly took stock of the sounds I could identify as he began to talk.

"Hey Joni. What are you doing here so late?" He was standing in the doorway.

"I guess I could ask you the same thing, Dr. Daynes." I could hear the computer fan whirring, the air conditioning running through the vents, the fluorescent lights, even a moth hitting the window, but there was a dead spot over behind the closet door. I couldn't quite tell for sure, but it seemed to me like there was a sound bubble in that closet. Maybe it was the woman whose voice I heard. Was Dr. Daynes hiding his date in there? What about the sound bubble?

"Yes, well, I am just here doing some research and writing," he smiled awkwardly and looked at me. "Can I help you with anything, Joni?"

"Yeah, well, I was downstairs practicing, and I heard some really weird sounds coming from up here. It was like singing, but not like any singing I have ever heard. Did you hear anything like that? It sounded like it was coming from here."

He shifted his weight from leaning on the door frame to standing upright and put on what I can only describe as a thinking face. It seemed disingenuous.

"Hmm ... interesting ... I don't think I heard anything like that." He looked around towards his desk, took two steps toward it, and picked up some headphones. "I was wearing these though. Maybe I didn't hear it."

Something was up.

Bickmore, Isaac. 2022. La Onda: The gatekeepers and the replicants. Action, Criticism, and Theory for Music Education 21 (1): 171-98. doi:10.22176/act21.1.171 
"Weird," I said with a disingenuous confused look of my own. "It was pretty loud and really interesting. I just wanted to see what it was. Sorry for bothering you, Dr. Daynes. Let me know if you hear weird singing ... or something. I'll see you in class tomorrow morning."

"No bother at all, Joni. See you tomorrow." Then he shut the door, and I saw through the small window that he put on the headphones. It was then I realized his headphones had not been plugged into anything. He was looking around the side of his computer trying to find where to plug them in. I started walking away and kept an ear on the room. The sound bubble in his closet and the weird way he was acting made me wary. I walked out of the building, turned the corner, leaned against the wall, and continued to listen.

The sound bubble that was in the closet began to grow, and I could tell that it was enveloping the whole office. I couldn't hear Dr. Daynes or anything in his office anymore. Was Dr. Daynes like me? As far as I knew, I was the only one who could do anything like bubble off sound and do sound scans and control sounds with my mind. My parents discouraged me from Googling stuff about my powers or from trying to see if there were other people like me, and other than the occasional search to satisfy my curiosity, I pretty much followed their rules and never found anything. I think they are worried about Google knowing stuff about me, and I totally get that. Google knows everything else about me. I should probably not tell them that I have superpowers.

I decided to wait for him to leave, so I stood outside just around the corner from the exit, checking my Instagram (so I could make sure Facebook knew more about me). Five minutes later the sound bubble burst. I heard the footsteps of two people walking towards the exit. I sound bubbled myself and hid by the air conditioning unit that was conveniently humming along. I hoped that by hiding by the air conditioner they wouldn't notice the absence of sound that my bubble created around me, they would just hear the air conditioning unit. If Dr. Daynes had powers like mine and was as good as me, he would be able to hear my heartbeat and breathing, if he was looking for them. He would also be able to tell if there was a dead spot like I could in his office. But he might not notice a dead spot if I was beside something loud. It was a risk doing what I did, but I am glad I did it.

Dr. Daynes walked out of the building first, and then someone with lighter footsteps followed. From my vantage point I could see the parking lot, and after 
listening to their footsteps approach, they finally came into my view. Dr. Daynes was looking over his shoulder right past me, and then I saw the woman. She was not Dr. Daynes's wife. At least she didn't look like the woman I saw him with at the Walmart a few weeks ago. Also, they were getting into a van for some plumbing company. The woman was wearing a black suit and tie. This was weird. Were they like having a weird loud make out session or something and I interrupted it? Why was that lady dressed in a black suit and tie like Janelle Monáe? Why were they leaving in a plumbing van? Who or what made that sound bubble around his office and why? I had never made one that big. Was that woman or Dr. Daynes like me? They drove away.

I decided to try and get some sleep. I started walking back to my dorm thinking about answers to those questions. It was already midnight and some change, and I had to go to class in the morning. I realized at that moment that the class I had to go to was Dr. Daynes's class-Intro to Music Education. It was one of my music classes that I actually kind of enjoyed. I liked it because we were talking about all kinds of stuff that wasn't just for choir or band teachers. Dr. Daynes was a general music teacher before he was a professor, and he tried to help us think about pedagogy (favorite new college word, it's just fun to say) and the many different things music education could be. He gave us a writing prompt at the beginning of the class a few weeks ago, and all it said was "What if music education..." and we were supposed to write a paragraph or two about it.

I wrote about an idea I had where I could do a song-writing thing with elementary school kids using chrome music lab and xylophones. Help them write rap lyrics and a hook and teach them how to do the chords and stuff. He left a comment on my Google doc saying we should talk more about it. We haven't talked about my idea yet, but I would love to. I will do that project even if I don't end up being a music teacher. I think I might switch to Elementary Education. There are 16 less credits in that degree, by the way, and I can always do music stuff as an elementary teacher. I don't know. I would love to teach elementary music but looking at what it takes to get there just makes me wanna barf. I wish there was a way I could do a general music degree. I looked into that actually and some universities have a third track, but you still have to take 4 years of voice lessons. From what I can find online, pretty much every school of music in the United States is focused on old dead white guy music. There are a few exceptions, but mostly the

Bickmore, Isaac. 2022. La Onda: The gatekeepers and the replicants. Action, Criticism, and Theory for Music Education 21 (1): 171-98. doi:10.22176/act21.1.171 
type of music I love and want to share with kids does not show up in college music schools.

In my dorm room I dropped my stuff by my bed and fell asleep thinking how weird it would be to see Dr. Daynes in class the next day.

\section{The Next Day}

I walked through the entrance of the music building and down the stairs that led right into my Intro to Music Ed classroom. I was about 3 minutes late. I looked in through the windows on the door. I could tell something was off, so I stopped on the stairs. All my classmates were extremely quiet, and Dr. Daynes was singing something. It sounded similar to the singing I had heard the night before in the practice room. Something about the singing made me sleepy. No. Not sleepy. Relaxed. I wanted to sit down and just stare at him. I felt like I needed to know everything he said. I realized that those feelings were stupid, so I quickly sound bubbled my ears. All my classmates were transfixed. Nobody looking at a phone, nobody fidgeting, nobody moving at all. All of them were just staring right at him. The people in the hallway seemed to be unaffected by the sound. Probably because they couldn't hear as well as I can.

I watched him from the middle stair, hoping he wouldn't see me. I waited for him to stop singing. He sang for a few more seconds and then stopped. He looked around at the class, and they did nothing. No applause, no shuffling, no movement, nothing. He sang another phrase. I was beginning to think Dr. Daynes was not Dr. Daynes anymore. At least not the Dr. Daynes I knew. What I saw next really scared me. Dr. Daynes began to speak. I unbubbled my ears.

"Everyone stand and repeat after me." He said it quietly and without urgency, but right after he said it, everyone in the class stood up immediately. Every one of my classmates stood up without the slightest hesitation. Dr. Daynes began to sing again.

"Elelelutianitzaeae."

The class echoed him.

Bickmore, Isaac. 2022. La Onda: The gatekeepers and the replicants. Action, Criticism, and Theory for Music Education 21 (1): 171-98. doi:10.22176/act21.1.171 
"Elelelutianitzaeae." They sang it exactly as he had, not missing a single vowel or consonant. He sang several more phrases quietly, and they echoed him. Then the whole class began to chant softly and in unison.

"We are ready to transmit the truthful transmission. All will sing and rejoice. We are ready to transmit the truthful transmission. All will sing and rejoice."

I kept feeling like I should do something, but I didn't know what was actually happening. Here is what I did know:

1. I heard something weird last night.

2. Dr. Daynes acted weird about it when I confronted him. (Probably because I interrupted his sexy office session with that weird lady.)

3. There was a sound bubble in his office that grew to the size of his office when I left the building.

4. He (maybe not Dr. Daynes at all) left the building with that weird lady (who was she?).

5. They left in a plumber's van (not sexy at all).

6. It looked like he (probably not Dr. Daynes) was brainwashing my classmates using his (whose?) voice.

7. I had to do something about it. (But what?)

8. I also knew where the fire alarm was. (That's what!)

The fire alarm was right next to the door of the classroom. I bubbled my ears, reached out, and pulled it. I looked through the window on the door and watched as my classmates began to awaken from the spell. They were talking to each other trying to figure out what had happened as they gathered their things. Dr. Daynes was looking around frantically like he had never heard a fire alarm before. He looked out the door window, and we made eye contact. His expression changed from confusion to sudden realization and then to an "I'm-gonna-get-you" kind of face.

I looked back at him and tried to make an "Oh-no-you're-not" kind of face, and then he started walking towards me, pushing desks and students out of his way. He kept his eyes on me, his brow furrowed, and his teeth gritted. The desks and my classmates gave me time to get out of there.

Bickmore, Isaac. 2022. La Onda: The gatekeepers and the replicants. Action, Criticism, and Theory for Music Education 21 (1): 171-98. doi:10.22176/act21.1.171 
I ran out of the building and towards the parking lot. I tried to hide behind a nearby car. As I did, I could see that the woman in the black suit was getting out of the plumber's van. She must have seen me running into the parking lot because she got out of the van and looked right at me. I didn't really have a plan, but I was starting to formulate something. Dr. Daynes, or something shaped like Dr. Daynes, walked up to the van, and stood beside the woman. They could see me, and they were just waiting for me to come out from behind the car. I stood up, straightened my clothes, and turned around to face them. I tried to look chill, but my mind was racing, "What should I do? What should I do?" The plan that was formulating in my mind took shape, and I made my first move.

"I know you are not Dr. Daynes," I said in a whisper. I was 100 yards away from them. "At least, I know you aren't acting like the Dr. Daynes I know." I could tell they could hear me. The woman stepped forward. The next thing I knew there was a voice in my head.

"You petulant child."

I fell over onto my knees. I had never experienced anything like it. It was like the sound came from within my skull. I quickly tried to push it out. She kept on speaking. "You play with things that you don't understand!" I found the sound source in my head and shut it out, and then I started to run. They started to follow me, just like I'd hoped. I looked over at the Christian Student Center where I had played bass a couple of times for the praise band and started booking it towards the front door. I was doing pretty good maintaining a sound bubble around me as I ran. It was hard, though, because they were trying to break through it. I had to break the lock on the door to the Christian Student Center by vibrating it until it snapped, which only took a second. I figured Jesus would forgive me.

I went into the chapel and thankfully nobody was there. There was a bass though, and it was plugged into an amp. I strapped it on. It was one of those beginner basses that Flea from the Red Hot Chili Peppers was trying to sell a couple of years ago. It was not as good as my Hoffner, but it would have to do. I turned on the amp and cranked the volume. I started laying down the bassline to "Tightrope" by Janelle Monáe. There was a loop pedal hooked up to the bass, so I clicked it and ran through the bassline again. If I was gonna have to fight these punks with sound, I wanted it to be on my terms.

Bickmore, Isaac. 2022. La Onda: The gatekeepers and the replicants. Action, Criticism, and Theory for Music Education 21 (1): 171-98. doi:10.22176/act21.1.171 
The bassline was looping as they ran into the chapel doorway and looked around. I was on stage waiting for them. I took one of the low F sound waves that had just pushed out of the amp and focused it all at the door where the two of them were standing. The man was not ready for it. He flew back and hit the wall behind the door. He passed out and slumped down on the floor. The woman was ready. She had sound-bubbled herself, but I was still able to push her back a bit. I heard her let down her guard, and I quickly bubbled off. I'm glad I did because it probably saved my life. She opened her mouth and let loose. I was able to hold my bubble for a second, but her sound blast was too powerful. She knocked me back on my butt behind the PA system for the chapel. I quickly stood up and searched the room for a sound I could push at her. I found a bass note from the Monáe bop and threw it at her. She quickly deflected it, and before I knew it she was in my head again. Her voice was anyways.

"Why are you fighting us?"

It hurt.

She was vibrating my skull, but I managed to reply, "Does 'us' include Mister Floppy over there by the door?"

Her eyes turned towards the door and then back at me.

"He will recover," she said, looking mean enough to kick a puppy.

"What the hell are you anyways?" I asked, as I tried to push her out of my head.

"We are the truth!"

She gave that last word an extra buzz in my skull.

"We are the truthful transmission. We have come to save this planet from itself."

“So, you are like ... aliens?” I asked. I had to keep her monologuing until I found something I could use against her.

"We are not of this planet. We are from far away."

She said it as if it was supposed to impress me.

"Don't care," I said, as my eye landed on a microphone on the floor a couple of feet away. I put my foot on the mic cord. The PA system was off, but I could see which input the mic was plugged into. I was really close to one of the speakers. If I could only get a hold of that microphone...

She walked slowly closer to me, as baddies are prone to do when they think they have you cornered. I was able to stop some of the buzzing and think at the 
same time, which surprised me because my head was throbbing with pain. I tried to kick the microphone closer to me as I asked this question.

"What's all this about truth and transmission?" The microphone was almost within my grasp.

"You are different from the rest. We were not expecting to find someone with the ability to do what we can do. You are inexperienced and your methods are crude, but you are powerful. I wonder just how powerful you are," she said menacingly and then the buzzing got worse.

“Aaaaahhhhh!” I screamed. I grabbed my ears and fell to my knees. As I did, the microphone rolled behind the PA system. Now if I could just lean over and grab it.

"You can do better than that, young one," she said as she inched closer. She was about 10 feet away now.

"SHUuut UP!" I yelled, really annoyed by her calling me "young one." That stopped her for a moment. I was trying as hard as I could to push her voice out of my head, but my bubbling wasn't working. So I tried a new tactic. I amplified what I was hearing. Instead of trying to reject her constant buzzing and the noise she had somehow implanted in my skull, I decided to make it louder. It hurt at first, but as soon as I got in sync with her vibes, it was better. I don't think she noticed what I was doing, or maybe she thought I had given up. I directed the sound through me like a conduit and up into the ceiling. Now I could hear everything she said right in my head, and it didn't hurt. I put my hand to my ear, pretending like it still hurt, and asked, "Here's another question, you stupid banshee. Why here? Why Charlesville, Missouri in the Hobart School of Music? What could you possibly accomplish by starting your evil plot here?”

I crouched down as though I was hiding and looked at the back of the PA. The microphone was within my reach. I slowly slipped my hand under the power cord and through the dust bunnies that had gathered behind the equipment.

"This place is the center of the most powerful nation on your planet. From here we can transmit the truth to all of your people. As far as the school of music is concerned, that is harder to explain."

"Try me, dummy," I said, peering at her over the PA system. I looked at the knobs on the back of the system to see if they were all turned up. 
"Very well," she said, "I will try to explain it to you." She started pacing three steps one way and then the other. Still, her voice seemed like it was coming from inside my head.

"What you call music is something like our highest form of communication. Here there is much more diversity of sound and practice. None of it as complex or beautiful as what we do, but still, some of it is impressive. We researched all the ways in which you divide your music. So many classifications. We watched for a long time to find the music that would best suit the transmission of the truth. We watched churches, studios, concerts, schools of all kinds, parks, homes, and everywhere music takes place all over your world. Most music making in your world is too unruly. There is no authority. It is too hard to tell who is in charge, and the conventions are constantly changing. Much of your popular and folk musics address your political and social issues. This makes things messy for us."

She stopped and looked at me.

"A school of music is the perfect place for our transmission to begin. In your schools of music, the conventions never change. With only a few exceptions, tradition is king in your conservatories. It is very orderly. You mostly focus on one type of performative music making. There is almost always a director figure who directs the music makers. There is a clear hierarchy. All of these factors make a school of music the best place for the truth to take seed. We have watched your planet for centuries. My colleague and I are the first of many who will come to transmit the truth and save you from your disorder and division. You will learn the song of truth through the transmission, and you will rejoice."

I couldn't help but agree with her about our school of music. She was evil and was probably going to kill me, but she was right. Old stuffy rules that never change with very few exceptions. Dr. Daynes was trying to be one of the exceptions. He had talked about what he called the $80 / 20$ problem. Only $20 \%$ of the secondary education population was taking music classes in high schools and middle schools. Most of that 20\% was white and most of those classes were either choir, band, or orchestra. That meant that a good $80 \%$ of the kids were not interested in choir, band, or orchestra. I was one of the $80 \%$. Crazy alien lady was actually helping me understand my own 80/20 problem. I love music, and I want to teach in an elementary school, but maybe going to a school of music was the worst way to do that. It certainly didn't feel right to me. I thought again about Dr. Daynes.

Bickmore, Isaac. 2022. La Onda: The gatekeepers and the replicants. Action, Criticism, and Theory for Music Education 21 (1): 171-98. doi:10.22176/act21.1.171 
"Hey buttface! Where is the real Dr. Daynes?" I asked as I slowly turned all the knobs to 11 on the back of the PA system. When I turned it on, I would get the maximum effect.

"Your Dr. Daynes is sleeping in his office. He has received the transmission, and when he awakens, he will be ready to sing the song of truth and rejoice. He is a gatekeeper. He decides who gets access to the youngest humans. We took his place to transmit the truth to your classmates. Most of your classmates will be in close contact with the youngest humans. They will transmit the truth to the children, and they in turn will transmit the truth to others. All will sing and rejoice."

I was ready. Her voice intensified and the sound reverberated around the room.

"Sure, sure. All will sing and rejoice." I held the microphone up to my mouth. She looked at me.

"What if I don't want to sing and rejoice?" I put my finger on the power switch. She stared.

"What if I..." I sat up straight...

“...just wanna make SOME FORKING”...

... ${ }^{*} \operatorname{click}^{*} \ldots$

"NOOOOIIIIISE!!"

I yelled that last word into the microphone, a long-sustained yell. My whole body trembled in sync with the vibrations that were emanating from the speakers. My head and the microphone were right in front of the speaker, and it had the desired effect. I had created a magnificently gnarly feedback loop. Simultaneously I had bubbled off my ears because they were right by the speaker. I refocused the sound of her voice, my voice, and the feedback loop all at her. She resisted for a hot minute and then couldn't anymore. The vibration was oppressive. It was relentless. Wave after wave washing over her, pushing her through the air. I stretched my free hand towards her as I continued to yell, focusing the waves right at her. The blast sent her flailing backwards through the air towards the replica of Dr. Daynes.

As she was falling, I remembered a story my dad tells about when I was young. I got really pissed about something, and I physically moved him with a scream. That is when he started calling me La Onda, or mi Onda, or the wave, or my wave. "Cálmate, Onda," he would start to sing to me. He always knew my weakness. I 
love to listen to my dad sing. He would sing all kinds of stuff. He made up a little song. It calmed me down every time. Still does.

$\begin{array}{ll}\text { Como se siente la vibracion de una onda? } & \text { How does one feel the vibration of a wave? } \\ \text { Te la sientes en tu cabezita redonda } & \text { You feel it in your little round head } \\ \text { Tu eres La Onda,Tu eres La Onda } & \text { You are the wave, You are the wave } \\ \text { Tu me llevas a traves de la tierra redonda } & \text { You carry me across the round earth } \\ \text { Cálmate, Onda } & \text { Calm yourself, Wave } \\ \text { Cálmate, Onda } & \text { Calm yourself, Wave }\end{array}$

As she hit the wall, her skin turned yellow, like, bright yellow, and then she fell forward on all fours. The replica of Dr. Daynes was no longer a replica. He was bright yellow as well, still wearing Dr. Daynes's clothes. Neither of them resembled the people they had replicated anymore. They looked vaguely human, but neither had any hair and each had a slight ridge on their heads that ran from their foreheads to their necks.

The woman looked at me, tired and surprised. I smirked back at her and kept sending the sound her way. She had bubbled off as soon as she fell forward after hitting the wall, but her bubble was getting smaller, like she couldn't control it. I didn't have anything else in my plan. I was as surprised as she must have been. What would I do if I beat her? Who could I tell? I couldn't, like, call the cops or the FBI or something. She raised one hand in the air and started singing. Almost as soon as she started, she and the other replicant disappeared.

\section{Four Weeks Later}

Dr. Daynes sat in his office on the last day of the semester thinking about how much the world had changed since the two aliens had entered his office a few weeks ago. It turns out there was other intelligent life in the universe after all, and it was hostile. The day after the aliens came, he woke up in his office closet when he heard the fire alarm. He was dressed in a plumber's suit. He found out from his students that one of the aliens had been impersonating him. Another professor had been found knocked out in her office across campus, and a plumber was found naked in his van. The plumber had been on the TV news programs telling everybody that the aliens that took his clothes were bright yellow humanoids.

Bickmore, Isaac. 2022. La Onda: The gatekeepers and the replicants. Action, Criticism, and Theory for Music Education 21 (1): 171-98. doi:10.22176/act21.1.171 
The FBI showed up at Dr. Daynes's office the day after he woke up. They didn't know much about the aliens, but from the stories that were being pieced together by the media, it seemed pretty clear that they didn't come in peace. The FBI didn't know where the aliens were from or how they got here, but they did have some tissue samples from the incident at the Christian Student Center. His student Joni had been involved somehow. Dr. Daynes thought about how Joni told him last week that she wouldn't be majoring in music ed anymore. He wasn't surprised, but he lamented her leaving, nonetheless. He had seen it before, and he had only been a professor for a few years. There was a pattern developing. Students on the fringes, students who were minorities, first generation college students, students whojust couldn't stand so much old dead white guy music, kept deciding to leave. He got it. He doubted his own degree choices all the time. He wished there was more room for different types of musical engagement in the school of music.

He told himself that he had to re-double his efforts and submit the gigantic curriculum proposal he had been working on for a year-and-a-half that would open up the music ed degree to more participatory music, more popular music, more relevant pedagogical practices. He was tired of losing students like Joni. He wanted a program that would attract students like her-multi-instrumentalists who had a knack for improvisation, musically and pedagogically. Students who weren't afraid to think differently, weren't afraid of music technology. Students who weren't married to the band/choir/orchestra industrial complex from the get-go. He didn't have many allies, though. Still, he couldn't help feeling that if he didn't make some changes to the degree, he would keep losing, or worse, never attract students like Joni and the unique perspectives she and others might bring to the profession. He told himself not to dwell on it. He could still help the students who remained to make changes to think critically and creatively about music and teaching. It's not as if Joni had superpowers or something.

Bickmore, Isaac. 2022. La Onda: The gatekeepers and the replicants. Action, Criticism, and Theory for Music Education 21 (1): 171-98. doi:10.22176/act21.1.171 


\section{About the Author}

Isaac Bickmore is a general music teacher at Maplewood and Lakewood Elementary in the North Kansas City School District. He works with Kindergarten through $5^{\text {th }}$ grade learners. Previously he was an assistant professor of music education at the University of Central Music where he worked with pre-service music teachers to help them think about expanding definitions of what is considered music education. He is a music educator, researcher, narrativist, and interdisciplinarian. His work, both in scholarship and in practice, centers around project-based learning, STEAM in music education, and student driven curriculum. He is lucky enough to be the father of two wonderful boys and husband to the coolest person in the world.

\section{References}

Barrett, Margaret S., and Sandra L. Stauffer, Eds. 2009. Narrative inquiry in music education: Troubling certainty. The Netherlands: Springer.

Bartolome, Sarah J. 2016. Melanie's story: A narrative account of a transgender music educator's journey. Bulletin of the Council for Research in Music Education 207-208: 25-47. https://doi.org/10.5406/bulcouresmusedu.207208.0025

Blanchard, Jay S., and Ursula Casanova. 1996. Modern fiction about school teaching: An anthology. Needham Heights, MA: Allyn \& Bacon.

Bradley, Deborah. 2007. The sounds of silence: Talking race in music education. Action, Criticism, and Theory for Music Education 6 (4): 132-62. http://act.maydaygroup.org/articles/Bradley6_4.pdf

Clair, Robin Patric. 2013. Zombie seed and the butterfly blues: A case of social justice. Rotterdam, The Netherlands: Sense Publishers/Springer. https://doi.org/10.1007/978-94-6209-308-9

DeLorenzo, Lisa C., and Marissa Silverman. 2016. From the margins: The underrepresentation of Black and Latino students/teachers in music education. Visions of Research in Music Education 27. http://www.rider.edu/ vrme

Hendricks, Karen S., and Dorothy. 2017. Negotiating communities of practice in music education: Dorothy's narrative. In Marginalized voices in music education, edited by Brent C. Talbot, 65-79. New York: Routledge. 
Hess, Juliet. 2019. Music education for social change: Constructing an activist music education. New York: Routledge.

Koza, Julia E. 2008. Listening for whiteness: Hearing racial politics in undergraduate school music. Philosophy of Music Education Review 16: 145-55. https://doi.org/10.2979/PME.2008.16.2.145

Leavy, Patricia. 2015. Low-fat love. Expanded anniversary edition. Rotterdam: Sense Publishers/Springer.

Leavy, Patricia. 2016a. Fiction as research practice: Short stories, novellas, and novels. New York: Routledge.

Leavy, Patricia. 2016b. American circumstance. Anniversary edition. Rotterdam: Sense Publishers/Springer.

Lechuga. Carlos. C., and Margaret Schmidt. 2017. Cultural straddling: The double life of a Mariachi music education major. In Marginalized voices in music education, edited by Brent C. Talbot, 80-98. New York: Routledge.

McCall, Joyce M. 2017. Speak no evil: Talking race as an African American in music education. In Marginalized voices in music education, edited by Brent C. Talbot, 13-27. New York: Routledge.

Minette, Sarah M. 2018. "Do I really want to do this now?" Negotiations of sexual identity and professional identity: An intergenerational collaboration with six gay and lesbian K-12 music educators. PhD diss., Arizona State University.

Nichols, Jeananne. 2013. Rie's story, Ryan's journey: Music in the life of a transgender student. Journal of Research in Music Education 61: 262-79. https://doi.org/10.1177/0022429413498259

Powell, Sean R., and Celeste. 2020. Outside in the music teaching machine: Remembrances of marginalization. The Bulletin of the Council for Research in Music Education 223: 26-41. https://doi.org/10.5406/bulcouresmusedu.223.0026

Robinson, Deejay, and Karen S. Hendricks. 2017. Black keys on a white piano: A Negro narrative of double-consciousness in American music education. In Marginalized voices in music education, edited by Brent C. Talbot, 28-45. New York: Routledge. 
Smith, Tawnya D., and Karen S. Hendricks. 2020. Narratives and reflections in music education: Listening to voices seldom heard. The Netherlands: Springer.

Talbot, Brent C., ed. 2017. Marginalized voices in music education. New York: Routledge.

Bickmore, Isaac. 2022. La Onda: The gatekeepers and the replicants. Action, Criticism, and Theory for Music Education 21 (1): 171-98. doi:10.22176/act21.1.171 